\title{
First report of the black gemfish Nesiarchus nasutus (Perciformes: Gempylidae) in Argentinean waters
}

\author{
Spath, MC. ${ }^{a *}$, Delpiani, G. ${ }^{a}$, Brunetti, NE. ${ }^{b}$, Sakai, M. ${ }^{c}$ and Figueroa, DE. ${ }^{a}$ \\ ${ }^{a}$ Laboratorio de Ictiología, Instituto de Investigaciones Marinas y Costeras - IIMyC, Facultad de Ciencias Exactas y \\ Naturales, Universidad Nacional de Mar del Plata - UNMdP, Consejo Nacional de Investigaciones Científicas y \\ Técnicas - CONICET, Funes 3350, Mar del Plata, B7602AYL, Argentina \\ 'Instituto Nacional de Investigación y Desarrollo Pesquero - INIDEP, Paseo Victoria Ocampo, 1, \\ Mar del Plata, B7603HSA, Argentina \\ ${ }^{\mathrm{c} N a t i o n a l ~ R e s e a r c h ~ I n s t i t u t e ~ o f ~ F a r ~ S e a s ~ F i s h e r i e s, ~ 2-12-4, ~ F u k u u r a, ~ K a n a z a w a-k u, ~ Y o k o h a m a-s h i, ~ 236-8648, ~ J a p a n ~}$ \\ *e-mail: ceciliaspath@gmail.com
}

Received: June 18, 2013 - Accepted: October 4, 2013 - Distributed: May 31, 2015

(With 2 figures)

\begin{abstract}
The gempylid Nesiarchus nasutus is reported for the first time from Argentinean waters, the southernmost occurrence of the species in the Southwestern Atlantic. This suggests that the fluctuating environmental characteristics of the area would be proper for the presence of tropical and subtropical species.
\end{abstract}

Keywords: southwestern Atlantic, Brazilian current, trichiuroids fish, deep-sea.

\section{Primeiro relatório do gemfish preto Nesiarchus nasutus (Perciformes: Gempylidae) em águas argentinas}

\section{Resumo}

A ocorrência de Nesiarchus nasutus é registrado pela primeira vez em águas argentinas, sendo a esta ocorrência mais meridional da espécie no Atlântico Sudoeste. Isto sugere que as características ambientais flutuantes da área seriam adequadas para a presença de espécies tropicais e subtropicais na mesma.

Palavras-chave: Atlântico ocidental sul, corrente do Brasil, trichiuroidea, águas profundas.

\section{Introduction}

The family Gempylidae comprises sixteen genera (Diplospinus, Epinnula, Gempylus, Lepidocybium, Nealotus, Neoepinnula, Nesiarchus, Paradiplospinus, Promethichthys, Rexea, Rexichthys, Ruvrttus, Thyrsites, Thyrsitoides, Thyrsitops and Tongaichthys) and 24 species (Nakamura and Parin, 1993; Roberts and Stewart, 1997; Nelson, 2006). This family is characterized by body oblong or elongate and compressed with two nostrils on the both sides of the snout. A large nonproctractile mouth with protruding lower jaw, strong teeth in jaws and exposed maxilla, two continuous dorsal fin, with the base of spinous dorsal fin longer than that of soft-rayed fin (excluding finlets). Anal fin similar to the second dorsal fin, with one to three spine and 8-35 soft rays; separated finlets present behind dorsal and anal fins in some species. Pectoral fin shorter than head and pelvic fin reduced or absent with one spine and five soft rays, caudal fin forked, one or two lateral lines. The number of vertebrae is 32-58 (Nakamura, 1986, 1990; Nakamura and Parin, 1993; Figuereido and Menezes, 2000; Nelson, 2006).
The snake mackerels Gempylidae are marine fishes that inhabit tropical and subtropical seas, often in very deep water (Nakamura, 1986, 1990; Nelson, 2006). They are typical meso- and bathy-pelagic fishes with worldwide distribution or fairly wide geographical migration (Nakamura, 1986, 1990). They are swift predators found in all oceans, usually in depths of $200-500 \mathrm{~m}$, but often migrating to the surface at night (Nakamura, 1986, 1990).

The black gemfish Nesiarchus nasutus Johnson 1862 is distributed worldwide in tropical and subtropical seas except in eastern Pacific and northern Indian oceans. Adults are bentho- to meso-pelagic, dwelling on the continental slope or underwater rises at about 200 to $1200 \mathrm{~m}$, and migrate to midwater at night (Nakamura and Parin, 1993). Larvae and juveniles are epi- to meso-pelagic, being quite common in oceanic ichthyoplankton, but only found in the tropic (Nakamura and Parin, 1993). Feed on squids, fish and crustaceans (Nakamura and Parin, 1993). 
The aim of this work is to report the range extension of the black gemfish Nesiarchus nasutus in the Southwest Atlantic.

\section{Material and Methods}

The specimen was caught using a bottom trawling [model: Nichimo MT-660-SR (MT) net trawling having $1500 \mathrm{~m}^{2}$ of mouth opening and $60 \mathrm{~mm}$ mesh in the cod end] by the R/V Kaiyo Maru cruise at $100 \mathrm{~m}$ deep.

The specimen was identified according to Nakamura and Parin (1993), fixed in formalin 4\%, preserved in 75\% ethanol and deposited in the Ichthyological Collection of the Instituto Nacional de Investigación y Desarrollo Pesquero, Mar del Plata, Argentina (INIDEP 838).

\section{Results}

The specimen of $N$. nasutus (Figure 1) reported here was caught off the Argentinean coast ( $38^{\circ} 32^{\prime} \mathrm{S}-52^{\circ} 03^{\prime}$

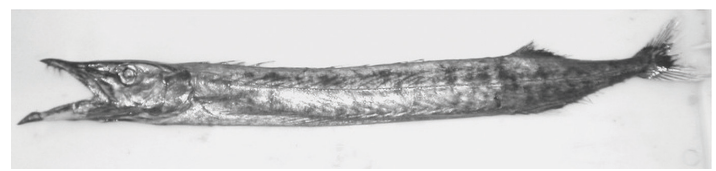

Figure 1. Specimen of Nesiarchus nasutus collected with a bottom trawling by the R/V Kaiyo Maru cruise.
W) on 14 October 2005 (Figure 2) with a temperature of $15.7^{\circ} \mathrm{C}$ and a salinity of 35.8 .

Diagnostic characteristics of $N$. nasutus agree with those described in the pertinent literature (Nakamura et al., 1983; Nakamura and Parin, 1993): body fairly elongate and strongly compressed; lower jaw beyond tip of upper jaw; vomer edentate; gill rakers degenerated; a single fairly straight lateral line, from above upper angle of opercula, gradually sloping posteriorly and running straight from mid first dorsal fin to caudal fin base. Body dark brown with violet tint; fin membranes black; margin of anus black. (Nakamura et al., 1983; Nakamura and Parin, 1993). Counts and measurements presented in Table 1.

\section{Discussion}

The black gemfish $N$. nasutus commonly inhabit tropical and subtropical waters; the larger specimens can reach cold-temperate waters off Iceland, Norway, northern Japan and southern New Zealand (Nakamura and Parin, 1993). The occasional presences of tropical and subtropical fishes in Argentinean waters are well documented in the literature (Cousseau and Figueroa, 1989; Díaz de Astarloa and Figueroa, 1995; Díaz de Astarloa et al., 2000; Figueroa et al., 2000; Rico and Acha, 2003; Scenna et al., 2006; Solari et al., 2010; Spath et al., 2012; Delpiani et al., 2013).

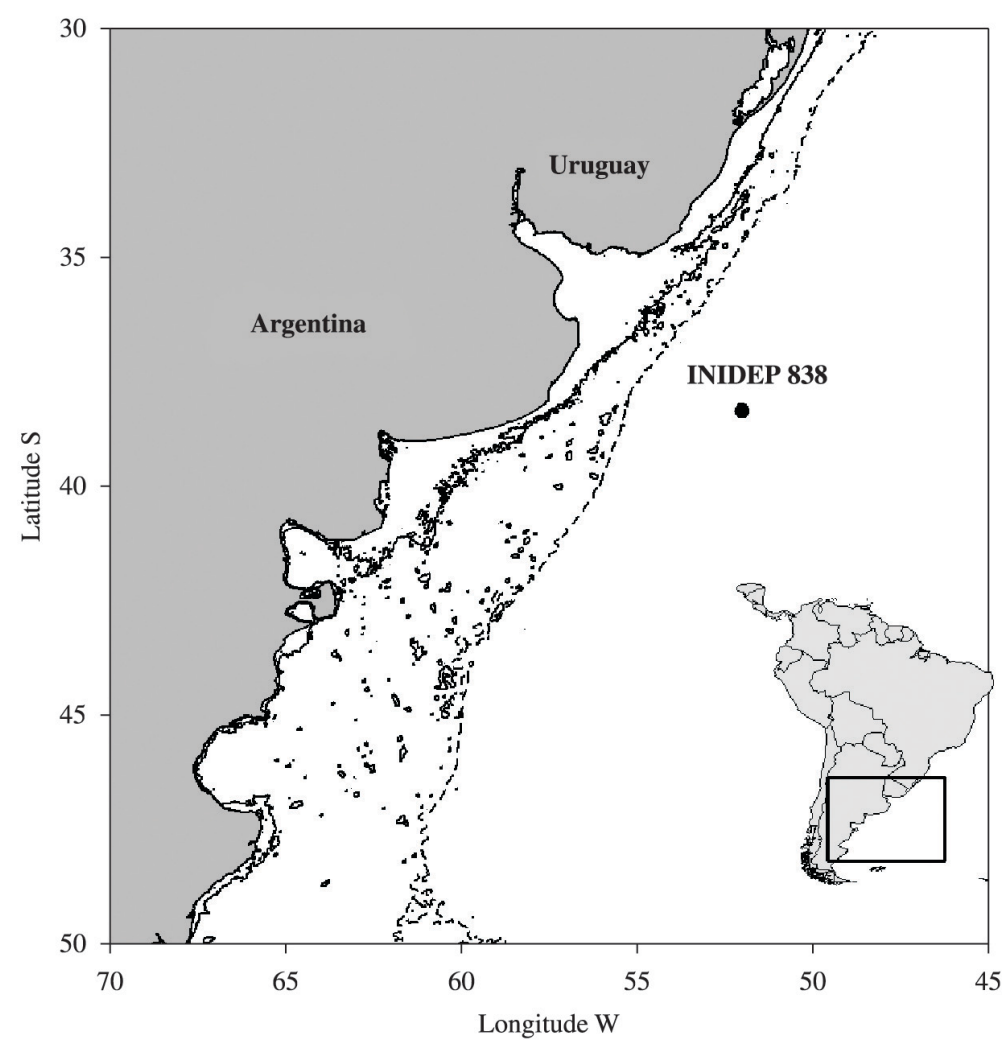

Figure 2. Map from the survey area where the Nesiarchus nasutus specimen was found. The 50 and $200 \mathrm{~m}$ isobaths are shown as solid and dashed lines, respectively. The rectangle inset shows the location of the study area in South America. 
Table 1. Morphometric measurements and proportional relationships $(\%$ standard length $=\% \mathrm{SL} ; \%$ head length $=$ $\% \mathrm{HL}$ ) for a single specimen of Nesiarchus nasutus caught off the Argentinean waters on 2005.

\begin{tabular}{|c|c|c|}
\hline & $\mathbf{m m}$ & $\% \mathrm{SL}$ \\
\hline Total length & 627 & \\
\hline Fork length & 585 & \\
\hline Standard length & 545 & \\
\hline Head length & 140 & 25.69 \\
\hline $1^{\text {st }}$ Pre-dorsal length & 130 & 23.85 \\
\hline $2^{\text {nd }}$ Pre-dorsal length & 429 & 78.71 \\
\hline Pre-pectoral length & 136 & 24.95 \\
\hline Pre-pelvic length & 143 & 26.24 \\
\hline Pre-anal length & 430 & 78.90 \\
\hline Head length & 153 & 28.07 \\
\hline Body depth & 59 & 10.82 \\
\hline Head depth & 50 & 9.17 \\
\hline Caudal peduncles depth & 21 & 3.85 \\
\hline & & $\% H L$ \\
\hline Snout length & 73 & 52.14 \\
\hline Upper-jaw length & 75 & 53.57 \\
\hline Pre-orbital length & 74 & 53.86 \\
\hline Inter-orbital length & 19 & 13.57 \\
\hline Eye diameter & 18 & 12.86 \\
\hline $1^{\text {st }}$ Dorsal fin elements & \multicolumn{2}{|c|}{ XIX } \\
\hline $2^{\text {nd }}$ Dorsal fin elements & \multicolumn{2}{|c|}{ I - 21} \\
\hline Anal fin elements & \multicolumn{2}{|c|}{ I - 21} \\
\hline Pelvic fin elements & \multicolumn{2}{|c|}{ I - 5} \\
\hline Pectoral ray fins & \multicolumn{2}{|c|}{13} \\
\hline
\end{tabular}

The Argentinean marine biogeographic province (Briggs and Bowen, 2012) is characterized by the encounter between the warm, southward-flowing Brazilian Current, and the cold, northward flow, of the Malvinas Current (Figueroa et al., 1998) and water discharge of continental output (Lucas et al., 2005). There is not clear explanation of how tropical and subtropical fish species arrive to the Argentinean province, but Scenna et al. (2006) and Seeliger and Odebrecht (1997) proposed that species of tropical and Antarctic waters might appear sporadically because they use the Brazilian and Malvinas currents as transportation. Another explanation for the occurrence of these species south of its range distribution may be phenomena such as eddies, which can be considered a quasi-stationary structured of Brazilian-Malvinas Confluence (Gordon, 1981). The southern boundary of the Brazilian warm water is accompanied by the intermittent formation of warm core anticyclonic eddies (Gordon, 1981; Olson et al., 1988) and represent a highly complicated system reflected in composition of mesopelagic fish fauna in the surveyed area. The generation of anticyclonic frontal vortices and their further displacement southward leads to the transport of thermophilic forms out of the sub-tropical zone to the sub-Antarctic (Figueroa et al., 1998). Beyond the explanations given above, it cannot be dismissed the possibility that this fishes are not occasional, but are part of a permanent population utilizing more southerly habitats than previously documented.

\section{References}

BRIGGS, J. and BOWEN, B., 2012. A realignment of marine biogeographic provinces with particular reference to fish distributions. Journal of Biogeography, vol. 39, no. 1, p. 12-30. http://dx.doi.org/10.1111/j.1365-2699.2011.02613.x.

COUSSEAU, MB. and FIGUEROA, DE., 1989. Peces de presencia ocasional en aguas marinas argentinas y uruguayas. Neotrópica, vol. 35 , p. 121-127.

DELPIANI, G., LÉRTORA, H., SPATH, P. and FIGUEROA, D., 2013. Occurrence of the flagfin mojarra, Eucinostomus melanopterus (Bleeker, 1863) (Perciformes: Gerreidae), near Mar del Plata city (Argentina): southernmost occurrence on the western Atlantic coast. Journal of Applied Ichthyology, vol. 29, no. 5, p. 1149-1151. http://dx.doi.org/10.1111/jai.12179.

DÍAZ DE ASTARLOA, JM. and FIGUEROA, DE., 1995. Scrawled cowfish, Acanthostracion quadricornis (Tetradontiformes, Ostraciidae), collected from argentine waters. Japanese Journal of Ichthyology, vol. 41, no. 4, p. 466-468.

DÍAZ DE ASTARLOA, JM., FIGUEROA, DE., COUSSEAU, MB. and BARRAGÁN, M., 2000. Occurrence of Trahinotus carolinus (Carangidae) in Laguna costera Mar Chiquita, with comments on other occasionally recorded fishes in Argentinean waters. Bulletin of Marine Science, vol. 62, no. 2, p. 399-403.

FIGUEREIDO, JL. and MENEZES, NA., 2000. Manual de peixes marinos do Sudeste do Brasil. VI. Teleostei. São Paulo: Museu de Zoologia Universidade de São Paulo.

FIGUEROA, D., DÍAZ DE ASTARLOA, E. and MARTOS, P., 1998. Mesopelagic fish distribution in the southwest Atlantic in relation to water masses. Deep-sea Research. Part I, Oceanographic Research Papers, vol. 45, no. 2-3, p. 317-332. http://dx.doi. org/10.1016/S0967-0637(97)00076-9.

FIGUEROA, D., DÍAZ DE ASTARLOA, E. and COUSSEAU, M., 2000. Southernmost occurrence of the aguavina on the western Atlantic coast of Argentina. Journal of Fish Biology, vol. 56, no. 5, p. 1280-1282. http://dx.doi.org/10.1111/j.1095-8649.2000. tb02140.x.

GORDON, A., 1981. South Atlantic thermocline ventilation. Deep-Sea Research, vol. 28, no. 11, p. 1239-1264. http://dx.doi. org/10.1016/0198-0149(81)90033-9.

LUCAS, A., GUERRERO, J., MIANZÁN, A., ACHA, W. and LASTA, C., 2005. Coastal oceanographic regimes of the Northern Argentine Continental Shelf $\left(34-43^{\circ} \mathrm{S}\right)$. Estuarine, Coastal and Shelf Science, vol. 65, no. 3, p. 405-420. http://dx.doi.org/10.1016/j. ecss.2005.06.015.

NAKAMURA, I., 1986. Gempylidae. In SMITH, MM. and HEEMSTRA, PC. (Eds.). Smith's sea fishes. Berlin: Springer. p. $825-828$

NAKAMURA, I., 1990. Gempylidae. In GON, O. and HEEMSTRA, PC. (Eds.). Fishes of the southern ocean. Grahamstown: JLB Smith Institute of Ichthyology Publishers. p. 402-403. Chapter X.

NAKAMURA, I. and PARIN, N.V., 1993. Snake mackerels and cutlassfishes of the world (families Gempylidae and Trichiuridae). An annotated and illustrated catalogue of the snake mackerels, 
snoeks, escolars, gemfishes, domine, oilfish, cutlassfishes, scabbardfishes, hairtails and frotfishes known to date. Rome: FAO Fishes Synopsis. 136 p. FAO Species Catalogue, no. 125.

NAKAMURA, I., FUJII, E. and ARAI, T., 1983. The Gempylid, Nesiarchus nasutus from Japan and the Sulu Sea. Japanese Journal of Ichthyology, vol. 29, no. 4, p. 408-415.

NELSON, JS., 2006. Fishes of the world. 4th ed. New York: John Wiley \& Sons. 601 p.

OLSON, DB., PODESTÁ, GP., EVANS, RH. and BROWN, OB., 1988. Temporal variations in the separation of Brazil and Malvinas Currents. Deep-Sea Research, vol. 15, p. 1971-1990.

RICO, M. and ACHA, E., 2003. Southernmost occurrence of Epinephelus marginatus in the South-west Atlantic. Journal of Fish Biology, vol. 63, no. 6, p. 1621-1624. http://dx.doi. org/10.1111/j.1095-8649.2003.00271.x.

ROBERTS, CD. and STEWART, AL., 1997. Gemfishes (Scombroidei, Gempylidae, Rexea) of New Caledonia, southwest Pacific Ocean, with description of a new species. No. 7. In SÉRET, B. (Ed.). Résultats des Campagnes MUSORSTOM. Mèmoires du Muséum National d'Histoire Naturelle. p. 125-141. vol. 17.
SCENNA, LB., SEGURA, V., DERISIO, C., FIGUEROA, DE. and DÍAZ DE ASTARLOA, JM., 2006. First occurrence of common snook, Centropomus undecimalis (Centropomidae), in Argentinean waters. Cybium, vol. 30, no. 2, p. 187-188.

SEELIGER, U. and ODEBRECHT, C., 1997. Introdution and overview. In SEELIGER, U., ODEBRECHT, C. and CASTELLO, JP. (Eds.). Subtropical convergence environments: the coast and sea Southwest Atlantic. Verlag: Berlin Springer Heidelberg. p. 1-3. http://dx.doi.org/10.1007/978-3-642-60467-6_1.

SOLARI, A., GARCÍA, M. and JAUREGUIZAR, J., 2010. First record of Eucinostomus melanopterus, Bleeker 1863 (Perciformes: Gerreidae) from the Río de la Plata estuary. Journal of Applied Ichthyology, vol. 26, no. 3, p. 485-487. http://dx.doi. org/10.1111/j.1439-0426.2009.01323.x.

SPATH, M., DELPIANI, C. and FIGUEROA, D., 2012. Southernmost record of antenna codlet Bregmaceros atlanticus (Goode \& Bean, 1886) (Gadiformes: Bregmacerotidae) in the Southwest Atlantic. Journal of Applied Ichthyology, vol. 28, no. 5, p. 831-833. http:// dx.doi.org/10.1111/j.1439-0426.2012.01946.x. 